University of Nebraska - Lincoln

DigitalCommons@University of Nebraska - Lincoln

Faculty Publications from the Harold W. Manter Laboratory of Parasitology

$12-1-2003$

\title{
A New Species of Mathevotaenia (Cestoda: Anoplocephalidae) and Other Tapeworms from Marsupials in Argentina
}

\author{
Scott Lyell Gardner \\ University of Nebraska - Lincoln, slg@unl.edu \\ Mariel L. Campbell \\ University of New Mexico, campbell@sevilleta.unm.edu \\ Graciela T. Navone \\ Centro de Estudios Parasitologicos y de Vectores, gnavone@cepave.edu.ar
}

Follow this and additional works at: https://digitalcommons.unl.edu/parasitologyfacpubs

Part of the Parasitology Commons

\begin{abstract}
Gardner, Scott Lyell; Campbell, Mariel L.; and Navone, Graciela T., "A New Species of Mathevotaenia (Cestoda: Anoplocephalidae) and Other Tapeworms from Marsupials in Argentina" (2003). Faculty Publications from the Harold W. Manter Laboratory of Parasitology. 20.

https://digitalcommons.unl.edu/parasitologyfacpubs/20
\end{abstract}

This Article is brought to you for free and open access by the Parasitology, Harold W. Manter Laboratory of at DigitalCommons@University of Nebraska - Lincoln. It has been accepted for inclusion in Faculty Publications from the Harold W. Manter Laboratory of Parasitology by an authorized administrator of DigitalCommons@University of Nebraska - Lincoln. 


\title{
A NEW SPECIES OF MATHEVOTAENIA (CESTODA: ANOPLOCEPHALIDAE) AND OTHER TAPEWORMS FROM MARSUPIALS IN ARGENTINA
}

\author{
Mariel L. Campbell, Scott Lyell Gardner*, and Graciela T. Navone $†$ \\ Museum of Southwestern Biology, Division of Mammals, University of New Mexico, Albuquerque, New Mexico 87131. e-mail: slg@unl.edu
}

\begin{abstract}
Cestodes are reported from Didelphis albiventris Lund, 1840 and Micoureus cinereus Temminck, 1824 (Marsupialia: Didelphidae) in Argentina. These include a new species of Mathevotaenia Akhumyan, 1946 (Cestoda: Anoplocephalata) as well as M. bivittata (Janicki, 1904) and an unknown hymenolepidid cestode. Mathevotaenia argentinensis $\mathrm{n}$. $\mathrm{sp}$. is characterized by a relatively narrow strobila, $18-37 \mathrm{~mm}$ in total length and $1.0-1.5 \mathrm{~mm}$ in maximum width, 135-163 craspedote proglottids, 1927 testes, and a muscular genital atrium. This species differs from M. didelphidis (Rudolphi, 1819) in the disposition of the genital ducts between the excretory canals and in the entrance of the vagina into the genital atrium posterior to the cirrus pouch; from M. paraguayae Schmidt and Martin, 1978 in the disposition of the genital ducts, absence of a seminal receptacle, and presence of an armed cirrus; and from M. boliviana Sawada and Harada, 1986 and M. pennsylvanica Chandler and Melvin, 1951 in the presence of an armed cirrus. Linstowiines appear to be the dominant cestodes in New World marsupials, with M. bivittata representing the most prevalent and widely distributed species. The hymenolepidid is the first record of this family in Neotropical marsupials.
\end{abstract}

Anoplocephalate cestodes of the subfamily Linstowiinae appear to be widely distributed in New World marsupials despite the paucity of published information on marsupial helminths in the neotropics. Five species of Mathevotaenia Akhumyan, 1946 have been reported from didelphid marsupials: $M$. bivittata (Janicki, 1904), M. didelphidis (Rudolphi, 1819) Spasskii 1951, M. marmosae (Beddard, 1914), M. pennsylvanica (Chandler and Melvin, 1951), and M. surinamensis (Cohn, 1902). Mathevotaenia (syn. Oochoristica) bivittata has been reported from numerous genera of didelphid marsupials in Brazil (Janicki, 1904; Janicki, 1906; Baer, 1927b; Pereira and Machado Filho, 1968; Santos, 1968; Pinto and Gomes, 1976; Gomes, 1979), Costa Rica (Flores-Barroeta et al., 1961), Panama (Foster, 1939), the West Indies (Sandars, 1957), and Bolivia (M. Campbell and S. Gardner, pers. obs.) and appears to be the most abundant and widespread cestode in neotropical marsupials. We provide the first report of this species from Argentina. In addition, we describe a new species of Mathevotaenia in marsupials from Argentina and report the occurrence of an unidentified species of Hymenolepis Weinland, 1858.

\section{MATERIALS AND METHODS}

\section{Collection localities}

Marsupials were collected from Moreno, Santiago del Estero Province, and from Orán, Salta Province, Argentina, by G.T.N. Moreno is located in the Chaco biogeographic province (Cabrera and Willink, 1973). The Chacoan thorn scrub plant community type occurs in semiarid areas with a marked dry season between May and October and a rainy season throughout the rest of the year. Mean annual precipitation ranges between 550 and $600 \mathrm{~mm}$, and mean annual temperature is $21-$ $22 \mathrm{C}$.

The Orán locality in Salta is located in the Yungas biogeographic province. The Yungas cloud forest extends from southern Venezuela southward to northwest Argentina along the eastern slopes or front range of the Andes (Cabrera and Willink, 1973; Unzueta, 1975). In Argentina, the southern boundary of the Yungas borders the Chaco, with yearly rainfall ranging from 500 to $1,200 \mathrm{~mm}$ and mean annual tem-

Received 13 November 1998; revised 22 May 2003; accepted 22 May 2003.

* To whom correspondence should be addressed. Harold W. Manter Laboratory of Parasitology, W-529 Nebraska Hall, University of Nebraska, Lincoln, Nebraska 68588-0514.

$\dagger$ Centro de Estudios Parasitológicos y de Vectores (CEPAVE), Calle 2, No. 54, 1900 La Plata, Argentina. peratures of 20-23 C. Marsupials infected with cestodes were collected in a transition zone between Yungas and Chacoan vegetation.

\section{Methods}

Cestodes were preserved in cold $70 \%$ alcohol and were not relaxed before fixation. Specimens were stained in Grenacher's acetic carmine, dehydrated in ethanol, cleared in terpineol and xylene, and mounted in Canada balsam. Drawings were made using a Leitz Ortholux II microscope with a drawing tube. Measurements and observations were made from whole mounts using a Zeiss Ultraphot II. Measurements are given in micrometers unless otherwise indicated; ranges are followed by means in parentheses. The holotype was deposited in the Colección Helmintológica del Departamento Científico de Invertebrados (CHDCI), Museo de Ciencias Naturales de La Plata, La Plata, Argentina; paratypes were deposited in the CHDCI and in the Harold W. Manter Laboratory of Parasitology, University of Nebraska-Lincoln, Lincoln, Nebraska. Mammalian symbiotypes (see Frey et al., 1992), when preserved, were deposited in the División Mastozoología, Museo Mar del Plata (MMPMa), Mar del Plata, Argentina.

\section{RESULTS}

Mathevotaenia argentinensis $\mathrm{n}$. sp.

(Figs. 1-6)

\section{Description}

Relatively small cestodes, $18-37 \mathrm{~mm}(28 \mathrm{~mm}, \mathrm{n}=3)$ in total length, consisting of 135-163 (149) craspedote proglottids. Maximum width 1,000-1,500 (1,300) attained in gravid segments just past midline. Scolex unarmed, poorly demarcated from strobila, 305-462 (387) long by 392-536 (452) wide. Suckers oval, with thin muscular walls, 222-256 (235) wide by 152-197 (169) long, each recessed into a pocket opening externally through a longitudinal slit down sucker midline. Opening at sucker anterior margin highly muscular and frequently constricted, so that sucker margin appears incomplete (Fig. 1). Neck 1,100-1,200 long by 320-370 wide; in some specimens, segmentation beginning immediately behind scolex. Developing genitalia first visible in 28th proglottid, 2-4 $\mathrm{mm}$ behind scolex; testes first visible in proglottid $64,4-6 \mathrm{~mm}$ behind scolex. First mature proglottid approximately segment 58-70; first gravid proglottid segments $86-102$. Strobila very slender for first one-fourth to one-third of the total length, increasing rapidly in relative width beginning in late immature proglottids. Immature proglottids much wider than long, length-width ratio of $1: 4$ to 1:7.5. Mature proglottids (Figs. 2, 5) 220-260 long 

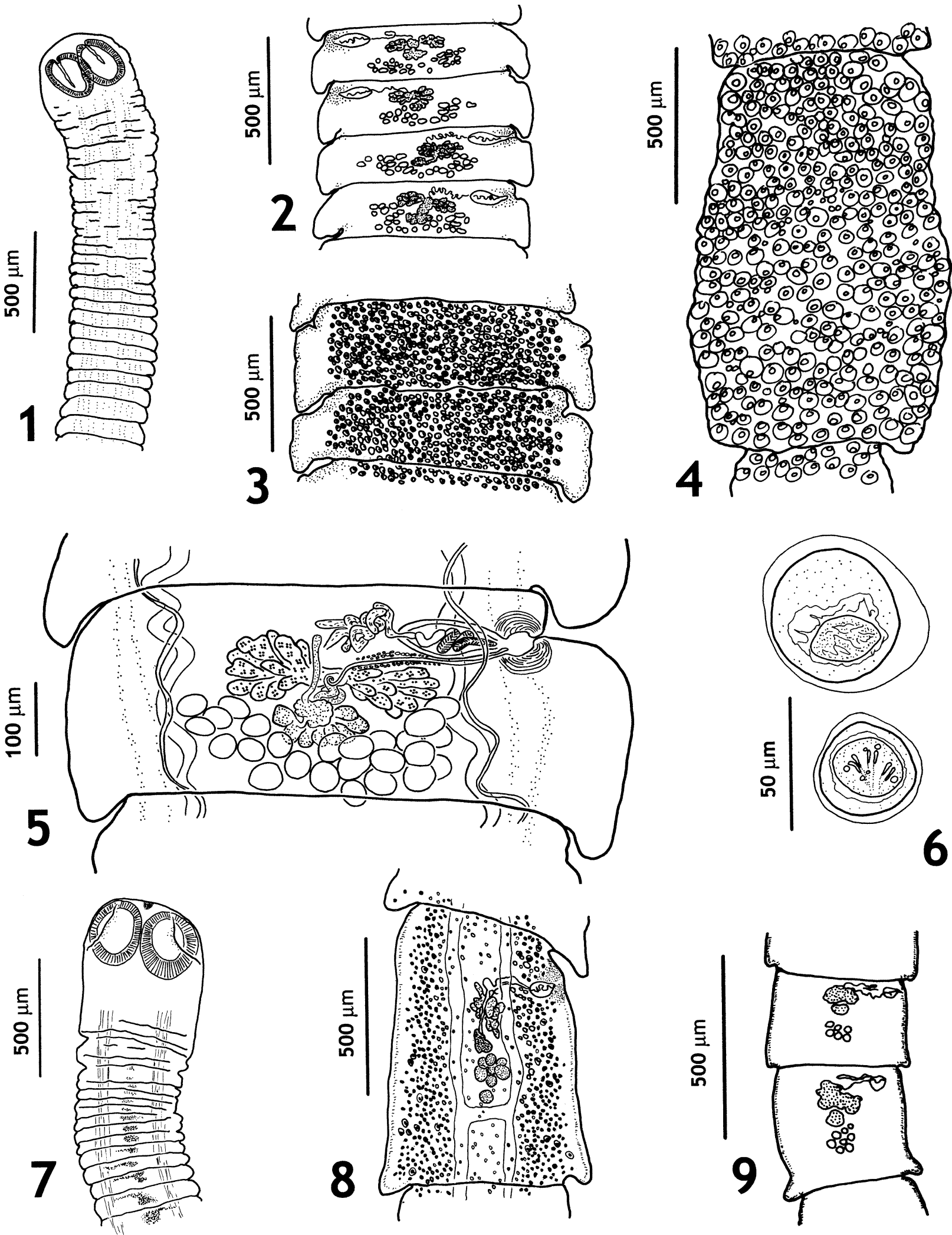

FiguRES 1-6. Mathevotaenia argentinensis n. sp. from Argentinian marsupials. 1. Scolex and neck region. 2. Mature proglottids. 3. Early gravid proglottids. 4. Late gravid proglottids. 5. Mature proglottid in dorsal view. 6. Eggs surrounded by outer egg capsule. FiguRES 7-9. Additional cestodes from marsupials in Argentina. 7. Mathevotaenia bivittata, scolex and neck region, showing suckers retracted into sucker pockets. 8. Mathevotaenia bivittata, gravid proglottid, showing persistence of genitalia and distribution of eggs along lateral margins. 9. Mathevotaenia bivittata, mature proglottids. 
by 780-1,000 wide. Gravid proglottids (Figs. 3, 4) 240-350 long by 1,080-1,490 wide at maximum width of strobila. Terminal gravid proglottids $640-1,330$ long by $570-650$ wide, barrel-shaped, packed with eggs. Female genitalia and testes involute in gravid proglottids, beginning in proglottids 100-110, where only cirrus pouch and sperm-filled fertilization duct are visible. Osmoregulatory system consisting of paired lateral canals, with narrow dorsal duct and broader ventral duct on each side. Genital ducts pass between osmoregulatory canals. Testes 19-29, in single field posterior and lateral to vitelline gland, reaching the posterior margin of ovary. Testes in poorly relaxed specimens irregular; in relaxed specimens oval to subspherical, 37-70 (53) long by 25-39 (34) wide. Cirrus pouch elongate, pyriform, with clear, thick external wall, 120-183 (142) long by $45-53$ (50) wide, narrowing markedly at proximal end where vas deferens enters. Lateral osmoregulatory canals crossing cirrus pouch midpoint. Cirrus pouch extending mediad to poral lobe of ovary, not reaching proglottis midline. Cirrus thick, highly coiled, armed with large spines readily visible at $\times 10$. Prostate cells visible at distal region of cirrus pouch. Internal and external seminal vesicles absent. Vas deferens forms highly coiled glandular duct anterior to ovary. Genital atrium pronounced, sphincterlike, 48-84 (63) deep by 5-24 (15) wide, encircled by strong bands of circular and radial musculature. Genital pores alternate irregularly, opening near anterior margin of proglottid. Ovary 90-168 (118) long by 286-324 (299) wide, medial, in anterior half of proglottid, bilobed, lobulate, with 1013 horizontal digitiform lobules on each side. Lobes of ovary not quite reaching lateral osmoregulatory canals. Vitelline gland medial, compact, in posterior half of proglottid, 72-96 (84) long by 126-163 (139) wide, with approximately 8 small rounded lobules oriented posterolaterally. Thin vaginal duct expanding slightly and becoming glandularized opposite poral lobe of ovary. Seminal receptacle absent. Oviduct a thick sinuous tube arising from ventral surface of ovarian isthmus, initially directed posteriad, then curving dorsally and anteriad, receiving narrow vagina and becoming fertilization duct. Broad, sperm-filled fertilization duct curves posteriad entering Mehlis' gland dorsal and anterior to vitelline gland. Vitelline duct arising from dorsal surface of vitelline gland, entering posterior border of Mehlis' gland and fusing with fertilization canal. Uterine duct passing forward from Mehlis' gland dorsal to ovary and vagina, descending into uterus anteroventral to ovary. Eggs initially appearing clustered in uterine pouches along ventral surface of the medulla, with maturing eggs becoming distributed singly in egg capsules throughout medulla and into cortical parenchyma; late gravid proglottids appearing as thin-walled sacs bulging with eggs (Fig. 4). Onchospheres (Fig. 6) (frequently deformed because of clearing) 26-32 (29) wide by 15-23 (18) long, surrounded by wrinkled envelope. Outer shell darkly staining, 4453 (49) wide by 30-49 (38) long. Egg capsules 63-74 (69) long by 55-62 (59) wide. Embryonic hooks 14.3-15 (14.7).

\section{Taxonomic summary}

Type host: Didelphis albiventris Lund, 1840 (2 individuals). Site of infection: Posterior half to one-third of the small intestine.

Prevalence: One hundred percent.
Intensity: Twenty to 40 worms per individual opossum studied.

Type locality: Moreno, Provincia Santiago del Estero, Argentina; $27^{\circ} 12^{\prime} 30^{\prime \prime} \mathrm{S}, 63^{\circ} 02^{\prime} 30^{\prime \prime} \mathrm{W}$.

Specimens deposited: One Holotype, slide no. II 200 A, CHDCI5283) and 3 paratypes, slide number C II 200 B, (CHDCI5284), slide no. C 180 A, (HWML17711) and slide no. C 180 B, (HWML17725).

Etymology: The species name refers to Argentina (argentinensis = of Argentina), the country in which it was found.

\section{Diagnosis}

Of the species of Mathevotaenia reported previously from neotropical marsupials, $M$. argentinensis n. sp. is most similar to $M$. didelphidis (Rudolphi, 1819) in having approximately 20 testes but differs in the following characteristics: (1) genital ducts pass between rather than dorsal to the excretory canals, (2) the cirrus pouch is oriented transversely rather than anteromediad, and (3) the vagina enters the genital atrium posterior rather than anterior to the cirrus pouch.

Flores-Barroeta et al. (1961) described cestodes from marsupials in Costa Rica, which they referred to Mathevotaenia (syn. Oochoristica) didelphidis (Rudolphi, 1819); however, their specimens differ from the original description of $M$. didelphidis in the characteristics of the cirrus pouch and vagina mentioned above and probably represent a distinct species. Mathevotaenia argentinensis differs from these Costa Rican specimens in having a much smaller scolex ( 0.3 by $0.4 \mathrm{~mm}$ vs. $1.2 \mathrm{~mm}$ in diameter), a much longer cirrus pouch (120-180 vs. 70-96) and, most importantly, mature eggs that are distributed evenly throughout the proglottids rather than concentrated along the lateral margins.

Flores-Barroeta et al. (1961) reported cestodes with 19-36 testes from $D$. marsupialis in Costa Rica and referred the species to $M$. pennsylvanica, originally described by Chandler and Melvin (1951) from North American shrews. Mathevotaenia argentinensis differs from these Costa Rican cestodes in having a much smaller scolex ( 387 by 452 vs. 760 by 1,170 ), a longer cirrus sac (120-180 vs. 660-1,060), an armed versus unarmed cirrus, and genital ducts passing between rather than dorsal to the osmoregulatory canals. Both $M$. argentinensis and the Costa Rican specimens described by Flores-Barroeta et al. (1961) differ from the original description of $M$. pennsylvanica by Chandler and Melvin (1951) in possessing a smaller strobila, fewer testes, testes distributed in a single field posterior to the female genitalia rather than in 2 lateral fields, a bilobed versus reniform ovary, and gravid segments that are longer than wide versus wider than long.

South American species of Mathevotaenia occurring in mammals other than marsupials and possessing only 20-30 testes include M. paraguayae Schmidt and Martin, 1978 from a South American armadillo and M. boliviana Sawada and Harada, 1986 from Bolivian bats. Mathevotaenia argentinensis differs from $M$. paraguayae in possessing genital ducts that extend between rather than dorsal to the osmoregulatory canals, by the absence of a seminal receptacle, and in having an armed cirrus highly coiled within the cirrus pouch. Mathevotaenia argentinensis is distinguished from $M$. boliviana by an armed versus unarmed cirrus, a much larger strobila, and a smaller scolex. 
Several individuals of $M$. argentinensis did not exceed 2-4 $\mathrm{mm}$ in length, appearing to have accelerated maturation of the strobila such that the first mature and first gravid proglottids occurred in segment numbers 23-32 and 30, respectively, of a total of 45 proglottids. In these specimens, the scolex measured 248 long by 284 wide with suckers 135 long by 103 wide, and the maximum width of the strobila was 119 to 162 . These specimens occurred in the same host individual as the type specimens and appear to be a forma minor of $M$. argentinensis (see discussion under $M$. bivittata).

\section{REDESCRIPTION}

\section{Mathevotaenia bivittata (Janicki, 1904) Yamaguti, 1959} (Figs. 7-9)

Synonyms: Oochoristica bivittata Janicki, 1904, 772; Linstowia [Opossumia] bivittata (Janicki, 1904) Spasskii, 1951, 498, figure 225; Opossumia bivittata Spasskii, 1981.

Literature: Janicki (1904, p. 772), Baer (1927b, p. 383), Foster (1939, p. 196), Spasskii (1951), Della Santa (1956), Sandars (1957, p. 337), Yamaguti (1959, p. 394), Flores-Barroeta et al. (1961, p. 191), Travassos (1965, p. 8, 29, 84), Pereira and Machado Filho (1968, p. 283), Santos (1968, p. 193-194, figures 1-2), Pinto and Gomes (1976, p. 54, 62, 63), and Gomes (1979, p. 591-592).

Small cestodes, 13-15 $\mathrm{mm}$ in length by $960-1,350$ in maximum width $(n=10)$. Maximum width in gravid proglottids in the posterior half or quarter of strobila. Scolex (Fig. 7) small, 360-390 long (measured to sucker posterior margin) by 460 600 wide, not globular or distinctly demarcated from strobila; width of strobila immediately behind scolex 280-620. Suckers 225-291 long by 201-228 wide. Sucker pockets present. Neck present or absent; genital anlagen visible immediately behind scolex or within $0.2-0.4 \mathrm{~mm}$. Thick bands of longitudinal muscle visible in whole mounts originating in scolex and running length of strobila. Proglottids craspedote, numbering 37-49, trapezoidal with laterally expanded posterior edges. Immature proglottids wider than long, length-width ratio of approximately 1:7. Mature proglottids (Fig. 9) wider than long in unrelaxed specimens, 194-197 by 400-601 (501); length-width ratio of 1:1.5-1:3.1. First mature proglottid segment 21-23; first gravid proglottid segment 24-28. Gravid proglottids (Fig. 8) wider than long to longer than wide; length-width ratio of 1:2.7 in early gravid proglottids to $1: 0.4-1: 1.4$ in terminal gravid proglottids, measuring 400-900 long by $600-900$ wide. Genital atrium small, 24-43 deep by 5-6 wide. Genital pores irregularly alternating, opening along anterior one-fourth of the lateral margin of proglottid. Cirrus pouch small, $71-108$ by 34-49, appearing as rounded pouch not quite reaching lateral osmoregulatory canals. Vas deferens forming numerous loops and convolutions medial to cirrus pouch, anterior and poral to ovary. Testes $10-13$, posterior to female genitalia at midline, subspherical, 23-31 long by 30-41 wide. Vagina opening into genital atrium posterior to cirrus pouch. Details of the vagina, including the presence of a seminal receptacle, were not distinguishable. The disposition of the genital ducts relative to the osmoregulatory canals was unclear in both whole mounts and sections because of the deformation of the strobila. Ovary 98 $209 \times 48-123$, medial, in anterior half of proglottid, not bilobed; a total of 10-15 short lobules are present oriented both dorsoventrally and anteroposteriorly. Vitelline gland compact, medial, 42-105 by 31-74, posterior to ovary, slightly lobed. Mature eggs (visible as darkly staining onchospheres) concentrated along the lateral margins of the proglottids and embedded in the cortical parenchyma (Figs. 8, 10). Female genitalia persistent throughout strobila, visible in the relatively clear area at the center of gravid proglottids. Terminal gravid proglottids contain very few eggs. Onchosphere 19-23 by 15-17; darkly staining outer shell 26 by 23 ; egg capsule $31-41$ by $23-29$. Hooks 11.8 in length.

\section{Taxonomic summary}

Hosts: Micoureus cinereus Temminck, 1824, symbiotypes MMPMa 2524 and 2525.

Site of infection: Small intestine.

Intensity: Eleven to 34 cestodes per host.

Locality: Orán, Salta Province, Argentina; 22 $59^{\prime} 40^{\prime \prime} \mathrm{S}$, $64^{\circ} 22^{\prime} 05^{\prime \prime} \mathrm{W}$.

Specimens: (\#24 a,e, and \#25 b CHDCI5285) and (\#24 B, \#25 A HWML17712).

\section{Remarks}

These specimens are similar to the original description and illustrations given in Janicki (1904), although the number of testes is greater than 5-8 and the strobila is much smaller than $55 \mathrm{~mm}$. Baer (1927a) reported individuals of this species from Brazil not exceeding $10 \mathrm{~mm}$ in length, which he referred to as a forma minor. Gomes (1979) also described small (4-6 mm) yet reproductively mature individuals with $8-10$ testes from Brazil, observing that smaller individuals tended to occur in hosts infected with large numbers of cestodes. All specimens examined in this study were taken from hosts infected with an average of 23 individuals, lending some support to Gomes' hypothesis that small body size in these cestodes may result from a "crowding effect" in heavy infections. However, we cannot rule out the possibility that these size differences may reflect underlying population or species-level genetic differences.

\section{ADDITIONAL OBSERVATIONS}

Three strobilar fragments of an unknown hymenolepidid cestode (specimen \#33, HWML17726) in poor condition were recovered from the small intestine of a single individual $\mathrm{M}$. $\mathrm{ci}$ nereus Temminck, 1824 (MMPMa 2533) from Orán, Salta Province, Argentina. These fragments appear to represent 3 individual cestodes, each lacking the scolex.

The only other report of a hymenolepidid from New World marsupials is a record of Hymenolepis sp. from D. virginiana virginiana from North America (Leigh, 1940). Leigh (1940) did not describe the morphology, noting only that "hooks were gone from rostella" (p. 192). It is possible that both the above reports represent accidental infections; however, several unique species of hymenolepids have been reported from marsupials in Australia. The Australian species include H. peramelidarum Nybelin, 1917, H. bradleyi Beveridge \& Barker, 1975, H. aklei Beveridge \& Barker, 1975, H. cercarteti Vaucher et al., 1984, H. antechini Vaucher et al., 1984, H. bettongiae Vaucher et al., 1984, H. isoodontis Vaucher et al., 1984, H. potoroi Vaucher et al., 1984, and H. peroryctis Jones \& Anderson, 1990 (see 
Vaucher et al., 1984). These species were transferred into the genus Vampirolepis Spasskii, 1954 by Jones and Anderson (1990) because of the presence of an armed rostellum. However, Vaucher (1992) rejected this transfer, suggesting that the hymenolepids of marsupials belong in their own genus (p. 301). Despite the lack of a scolex available for comparison, the unknown species from Argentina closely resembles $H$. cercarteti in the arrangement of the genitalia. The possibility that marsupials in the neotropics and in Australasia share similar species of hymenolepidid cestodes awaits verification.

\section{ACKNOWLEDGMENTS}

This work was funded in part by United States National Science Foundation grants DEB-9496263, BSR-9024816, and DEB-0097019 to S.L.G.

\section{LITERATURE CITED}

BAER, J. G. 1927a. Monographie des cestodes de la famille des Anoplocephalidae. Bulletin Biologique de France et de Belgique Supplément 10: 241.

. 1927b. Die Cestoden der Saugetiere Brasiliens. Abhandlungen der Senkenbergischen Naturforschungsgesellschaft 40: 377-386.

Beveridge, I., AND I. K. BARKer. 1975. Acuariid, capillariid and hymenolepidid parasites of the dasyurid marsupial Antechinus stuartii Macleay, 1841, from southeastern Australia. Journal of Helminthology 49: 211-227.

Cabrera, A. L., ANd A. Willink. 1973. Biogeografía de América Latina. Departmento de Asuntos Científicos, Organización de los Estados Americanos, Washington, D.C., 120 p.

Chandler, A. C., And D. M. Melvin. 1951. A new cestode, Oochoristica pennsylvanica, and some new or rare helminth host records from Pennsylvania mammals. Journal of Parasitology 37: 106-109.

Della SAnta, E. 1956. Revision du genre Oochoristica Lühe (Cestodes). Revue Suisse de Zoologie 63: 1-113.

Flores-Barroeta, L., E. Hidalgo-Escalante, and F. Montero-Gei. 1961. Céstodos de Vertebrados VIII. Revista de Biología Tropical 9: $187-207$.

Foster, A. O. 1939. Some helminths of the woolly opossum in Panama. Transactions of the American Microscopical Society 58: 185-198.

Frey, J. K., D. W. Duszynski, W. L. Gannon, T. L. Yates, and S. L. GARDNER. 1992. Designation and curation of type host specimens (Symbiotypes) for new parasite species. Journal of Parasitology 78: 930-932.

Gomes, D. C. 1979. Contribuição ao conhecimento dos helmintos parasitos de marsupiais no Brasil, da Coleção Helmintologica do In- stituto Oswaldo Cruz (Cestoda, Archiacanthocephala e Linguatulida). Revista Ibérica de Parasitología 39: 587-599.

JANICKI, C. vON. 1904. Zur Kenntnis einiger Säugetiercestoden. Zoologischer Anzeiger 27: 770-782.

. 1906. Studien an Säugetiercestoden. Zeitschrift für wissenschaftliche Zoologie 81: 505-597.

Jones, A., AND T. J. C. ANDERSON. 1990. Helminths of rodents and marsupials from Papua New Guinea, with the description of two new species, Echinostoma echymiperae n. sp. (Digenea: Echinostomatidae) and Vampirolepis peroryctis n. sp. (Cestoda: Hymenolepididae). Systematic Parasitology 15: 223-237.

LeIGH, W. H. 1940. Preliminary studies on parasites of upland game birds and fur-bearing mammals in Illinois. Illinois Natural History Survey Bulletin 21: 185-194.

Pereira, R. C. S., AND D. A. Machado Filho. 1968. Contribuição ao estudo de fauna helmintológica da Amazônia. Revista Brasileira de Biologia 28: 283-288.

Pinto, R. M., AND D. C. Gomes. 1976. Contribuição ao conhecimento da fauna helmintológica da região Amazônica-Cestódeos. Memorias do Instituto Oswaldo Cruz 74: 53-64.

SANDARS, D. F. 1957. Redescription of some cestodes from marsupials II. Davaineidae, Hymenolepididae and Anoplocephalidae. Annals of Tropical Medicine and Parasitology 51: 330-339.

SANTOS, E. DOs. 1968. Rediscrição de Mathevotaenia bivittata (Janicki, 1904) parasito de marsupial (Cestoda, Linstowiinae). Atas da Sociedade de Biologia do Rio de Janeiro 11: 193-194.

SpassKII, A. A. 1951. Essentials of cestodology. In Anoplocephalate tapeworms of domestic and wild animals Volume 1. K. I. Skijabin (ed.). The Academy of Sciences of the USSR, Moscow, Russia, $783 \mathrm{p}$.

- 1981. Review of the classification of the linstowiids. Izvestiya Akademii Nauk Moldavskoi SSR. Biologicheskie I Khimicheskie Nauki 6: 54-60.

Travassos, L. 1965. Contribução para o Inventário crítico da zoologia no Brasil. Fauna helmintológica: considerações preliminates-Cestódeos. Publicações Avulsas do Museu Nacional, Instituto Oswaldo Cruz, Rio de Janeiro, Guanabara, Brazil, 84 p.

Unzueta, O. Q. 1975. Mapa Ecológico de Bolivia: Memoria explicativa. Ministerio de Asuntos Campesinos y Agropecuarios, División de Suelos, Riegos e Ingenieria, La Paz, Bolivia, 309 p.

VAUCHER, C. 1992. Revision of the genus Vampirolepis Spasskii, 1954 (Cestoda: Hymenolepididae). Memorias do Instituto Oswaldo Cruz, Rio de Janeiro 87(Suppl. I): 299-304.

- I. Beveridge, and D. M. Spratt. 1984. Cestodes du genre Hymenolepis Weinland, 1858 (sensu lato) parasites de Marsupiaux australiens et description de cinq especès nouvelles. Revue Suisse de Zoologie 91: 443-458.

YAMAGUTI, S. 1959. Systema helminthum, vol. II. Cestoda. Interscience Publishers, Inc., New York, 394 p. 